\title{
It Is Easy When You Are a Christian: Badeng Kenyah Conversion to Christianity
}

\author{
Tan Chee-Beng \\ Sun Yat-sen University, Guangzhou, China
}

\begin{abstract}
In this article, I explore how the Long Geng Badeng Kenyah community of Sarawak converted to Christianity even though there was no sustained missionary persuasion from the outside. Over a period of study, I eventually accept the simple emic explanation that "it is easy when you are a Christian" to be an important explanation. Central to this view is that Christianity provides an alternative religion that allows the people to avoid the need to observe the many troublesome taboos that hinder frequent traveling and engaging in various kinds of economic activities. The influence of relatives is an important factor, too, and as more people become Christians, the traditional Bungan followers lose the support to continue with the traditional religion and eventually almost all follow their relatives to adopt the new religion, which they find do not hinder practicing their culture other than replacing the traditional worship with the Christian way. The ethnographic study provides the opportunity to relate to recent scholarship on the anthropology of Christianity, and facilitates anthropological reflection on the study of cultural change, in particular, in relation to the work of Marshall Sahlins.
\end{abstract}

Keywords: Christian conversion, Adet Bungan, Badeng Kenyah, Sarawak, SIB Church

\section{Introduction $^{1}$}

The spread of Christianity worldwide has been a phenomenal historical process. The conversion of indigenous peoples in particular has attracted the attention of anthropologists. Certain themes have remained popular, such as Christianity as representing the modern and conversion seen as a way of engaging with the modern world and as a means of empowerment, or Christianity as bringing about modern technology, modern material benefits and literacy, etc. These themes are well discussed in the special theme collection "Protestants and Traditions in Southeast Asia", edited by Charles F. Keyes and published in the Journal of Southeast Asian Studies (volume 27, number 2, 1996), see in particular the introduction by Keyes (1996). Of interest is the argument that conversion to Christianity allows the indigenous people to draw boundaries with the majority of people who are of different faiths. Yoko Hayami (1996), for example, argues that in the case of the Karen in Thailand, "Christian conversion differentiates them from Buddhist Thai" (Hayami, 1996, p. 349). In similar perspective and linking up with modernity, James Scott points out that Christianity in the Southeast Asia massif (upland regions of mainland Southeast Asia and the India-Bangladesh-Burma border areas which in his book is

Tan Chee-Beng, Ph.D., Distinguished Professor, Dept. of Anthropology, Sun Yat-sen University.

Correspondence concerning this article should be addressed to Tan Chee-Beng, Department of Anthropology, Sun Yat-sen University, 135 Xigangxi Road, Guangzhou 510275, Guangdong, China.

1 Acknowledgment: The 2014 field trip to Sarawak was supported by "Sun Yat-sen University Bairen Jihua" start-up fund (project No. 23000-3281302). 
described as Zomia) was a "resource for distance and modernity" (Scott, 2010, p. 319). This is an important argument although in each particular case one should look for historical and ethnographic evidence instead of merely assuming that this is so.

In paying attention to the people who have become Christians, researchers have significantly paid attention to the interpretation of Christianity in local cultural setting, as shown in the works of Aragon (1996) and Kammerer (1996). Others like Kirsch (2008) and Jean Commaroff (1985) have paid attention not only to the agency of the church leaders but also to the political economy. The later and also that of John and Jean Comaroff (1992) also discuss what they appropriately call the colonization of consciousness and the consciousness of colonization, showing the articulation of resistance to domination. Since the 1990s, there are many more works dealing with globalization, cultural change, and modernity (e.g. Coleman, 2000; Hefner, 1993; Tomlison, 2009; Robbins, 2004), and indeed many aspects in the anthropology of Christianity (Cannell, 2006; McDougall, 2009; Robins, 2007). Of interest to this paper is the analysis of the agency and calculation of the local people to convert. Amster (2009, p. 316) mentions that after the Second World War, the Kelabit in Sarawak "converted in large numbers in great zeal, now with the explicit encouragement of their leaders, who wanted to be more closely associated with powerful outsiders." Hefner (1993) gives a picture of conversion in Muslim Java as involving careful communal decision, balking at conversion to Christianity in the 1920s and contemplation about conversion became easier only since the 1970s.

In this article ${ }^{2}$, I describe the religious conversion of Badeng Kenyah, an indigenous people in Sarawak, Malaysia. I seek to understand how and why, despite the lack of sustained missionary persuasion from outside, the people converted to Christianity. Asked why they converted to Christianity, most people commented that their old way (referring to the old religion) was troublesome or that in the past people drank a lot of rice beer (borak) and were often drunk; Christianity saved them from this dire condition. I treated this as a post-conversion logic of conversion and I had heard this same reason from other indigenous peoples in Sarawak like the Lun Bawang and the Kelabit, who had all converted to Christianity. I eventually realized that the frequent comment about their "old custom" (adat puun) with many taboos as troublesome was a serious comment. A local leader commented that "it is easy when you are a Christian, you just use your mouth (i.e. pray to God), you don't have to sacrifice a chicken or a pig." At first I treated this skeptically as a legitimization for becoming Christians. Having been in touch with the people over a number of years, I eventually realized that this was a sincere view, that is, as much as I could feel and judge from my ethnographic research. Becoming Christians is a way of escaping from the cumbersome trapping of some old traditions, especially those having to do with cumbersome prohibitions.

The recent scholarship on the anthropology of Christianity provides theoretical understanding about conversion. "Rupture is central to the Christian experience," as Lampe $(2010$, p. 80) has observed. The significance of rupture is most forcefully articulated by Joel Robbins in his critique of anthropology as "a science of continuity" and that anthropological theories "emphasize cultural continuity as opposed to discontinuity and change" (Robbins, 2007, p. 5). With regards to Christian conversion, he points out that this

\footnotetext{
${ }^{2}$ Preliminary versions of this paper had been verbally presented at the International Conference Religion, Business, and Contestation in Southeast Asia, organized by University of Malaya \& Southern Methodist University, 27-28 June 2012, and at the XVIII ISA World Congress of Sociology, 13-19 July 2014, Yokohama. The research is based on anthropological field trips conducted since 1992. The field work in Long Geng before relocation was conducted in June 1992, August 1994, and April and May in 1995. The field trips after relocation to Sungai Koyan were conducted in July and August 2000, August 2008 and June 2014.
} 
involves "a radical rupture with and rejection of the past than it is with any more messy notion of change" (Robbins, 2010, p. 637). While the Badeng conversion did not involve the activities of missionary stations directly, as in the many studies of Christian conversion such as those of John Barker (1993) and Joel Robbins (2004), the idea of rupture is, nevertheless, relevant. However, the rupture involving the act of conversion does not necessarily mean rejecting all of the past. This paper shows that in the case of the Badeng, it is the use of Christianity to reject certain aspects of the past, while adjusting most of their cultural life to living as Christians, and vice versa, that is, integrating Christianity to their Badeng ways of life. In this respect, Marshall Sahlin's theoretical discussion of continuity and change is relevant. His views that culture is historically produced and altered in action (Sahlins, 1985, p. vii) and cultural change as "externally induced yet indigenously orchestrated" (Sahlins, 1985, p. viii) will be reflected in our discussion on Badeng conversion.

The aim of this paper is modest yet not straight forward, that is, to describe the process of conversion to Christianity among the Badeng, taking advantage of my anthropological observation over a period of time and the insight gained from the recent scholarship on the anthropology of Christianity. The conversion of the community is a gradual process, as Liana Chua has also observed in her study of the Bidayuh, which she describes as "gradual and piecemeal" (Chua, 2012, p. 515). The Badeng conversion is very much the people's own rationalization and selection in their encounter with Christianity amidst the changing world around them. Christianity arrived at a time when people were ready to accept changes to their traditional way of life. The lack of an exclusive religious ideology allows the Badeng to choose a new god and religious worldview without much difficulty. At the same time, the ability of the people to interpret Christianity in relation to their indigenous culture and the changing world also accounts for the apparent ease of conversion to Christianity. As there are still rather few studies on the Badeng of Sarawak, this paper will provide as much relevant ethnographic information as it is relevant to do so ${ }^{3}$.

Instead of relating the Badeng conversion to modernity with sophisticated theoretical discussion, which does not necessarily reflect how the Badeng feel and perceive, I shall show that the conversion has been a slow mundane process of Badeng choosing to replace some old beliefs with Christianity brought about by a number of processes. This is why I mention that the aim is not straight forward as the conversion cannot be easily attributed to any major factor. I thus seek to understand why eventually all the Badeng in the village that I have observed converted to Christianity by discussing internal factors in the village as well as locating the village in the larger regional perspective of missionary activities in Borneo, Sarawak in particular. The regional perspective helps to better understand how Christianity offered an alternative for escaping from the trapping of some old traditions. As to internal factors, we shall pay attention to the roles of local agents, such as the roles of a few local informal preachers and the role of converted kin in directly and indirectly bringing relatives to become Christians. Central to our understanding of the conversion is the agency of the indigenous people to rationalize and choose a new religious affiliation and their ability to practice the new faith as part of their culture while practicing some traditional culture in the form of the new faith.

The article will thus begin with a brief description of Badeng history of migration and settlement, as well as village fission and conversion in the course of this brief history. This will be followed by a description of the old Bungan faith, and the events of conversion to the Protestant and Catholic faiths. The description thus far offers an understanding of the process of conversion. How the people in the interior practice Christianity will

\footnotetext{
${ }^{3}$ For publications on the Badeng of Sarawak, see Armstrong (1994), Tan (1997, 2009) and Vom Roy (1993). There are two doctoral theses, see Armstrong (1991) and Jehom (2008).
} 
be briefly described as this will provide the background to understanding the continuity of indigenous culture in the context of conversion (transformation). The section on conversion and Badeng culture will provide some examples of how some traditional practices are retained in the people's practice of Christianity. In the conclusion, I will discuss the findings in the light of anthropological study of structure and change and the anthropology of Christian conversion.

\section{Brief Historical Background}

The Badeng belong to a category of people called Kenyah in Central Borneo which lies in the borderland of Indonesia and Malaysia. They identify themselves as Badeng and also as Kenyah, and they speak a Kenyah dialect that is distinct from other Kenyah groups. They regard Usun Apau, now in the Peliran region of Sarawak in Malaysia, as their homeland, from where their ancestors migrated to Apau Kayan in today's Kalimantan in Indonesia to avoid the harassment of the Iban and the Brooke regime that ruled Sarawak then. The Badeng of Long Geng originally came from Long Batang in Kalimantan (Indonesian side of Borneo), from where they re-migrated to Sarawak. A few old individuals still alive when I did the research in the early 1990s were born in Long Batang and so the re-migration was recent in the early 20th century. Lawai Laing, a Badeng leader interviewed in 1995 (since passed away) was born in Long Batang, and he confirmed that the Badeng who migrated from there split at Long Betao. From there the "Long Geng" group moved to the upriver of Pengian (Pengiyan), arriving eventually at Long Iran where they lived for a few years before moving to Long Besungai of the Linau River, a tributary of the Balui, in Sarawak. From there they moved upstream and reached Tekulang where they lived for at least 10 years. They were still at Tekulang during the Second World War. After the war, these Badeng moved to Long Geng around 1950, at the place where the Geng River flows into the Keluan, and so they were identified as people of Long Geng. Long Geng is in the Belaga District of interior Sarawak, and it took about six hours of difficult boat journey over some rapids to reach from the interior bazaar town of Belaga. From Belaga one traveled up the Balui River; soon after the Bakun Rapid the boat turned into the Linau River to move up to Keluan. Up to the 1980s, Long Geng was still a rather remote community in interior Sarawak. However, by the early 1990s, logging was so intense that there were logging roads that almost reached Long Geng.

When I first visited Long Geng in 1992, there were nine long houses on both sides of the Keluan River, connected by an old wooden suspension bridge. The settlement was spatially divided by religion with the Catholics and a few Bungan families (see below) on the right bank and the SIB Christians on the left bank. SIB (from the Malay name Sidang Injil Borneo) refers to the Protestant mission that is popular in Sarawak especially among the indigenous people. The history of SIB can be traced to the Australian mission called Borneo Evangelical Mission (BEM) which began its missionary work in Sarawak in 1928, and SIB as the local mission that grew out of BEM was established in 1959 (Lees, 1979, p. 28; Tan, 2011). In 1995, I calculated 196 apartments in Long Geng, although in 1992, I found only 150 apartments. The increase was due to the building of new apartments in anticipation of relocation because of the Bakun Dam project and the possibility of obtaining compensation. There were then around 1,200 people including individuals who had left temporarily to work at the logging camps ${ }^{4}$. In 1998, the villagers were relocated to Sungai Koyan in Bintulu District (see below).

\footnotetext{
${ }^{4}$ In 1994, there were 1,288 people according to the statistics collected by the local upriver agent (URA).
} 


\section{From Adet Bungan to Christianity}

The Badeng indigenous religious practices were called adet puun (old customs) ${ }^{5}$, which by the 1950 s were being replaced by adet Bungan that reformed the old practices by dropping some of the troublesome observation of bird omens and prohibitions. Informants talked of the interruptions of work and traveling caused by observing adet sui or "bird custom". For example, when a kind of bird called isit flew pass from the left, it was considered a bad omen, and people on their way to work or a destination would have to turn back or return home. Informants also mentioned pelaki, telajan and okeng birds which were used for reading omens; okeng in particular can make different kinds of voices and so were most important for predicting omens.

Adet Bungan was introduced by a Lepo Jalan Kenyah from Apau Kayan, called Jok Apoi, who had also traveled to the Sarawak side of the border. My old informant Nyuga (since deceased) mentioned that in his young days, he met Jok Apoi at Long Bah (downstream from Belaga), who was then an old man. Whittier (1978, p. 119) mentions that Adet Bungan began in the Apau Kayan in the mid 1940s and that the new faith was more popular among the Kayan and Kenyah of Sarawak than in the Indonesian side of the border. Indeed Adet Bungan spread to the Balui region in Sarawak and by the early 1950s most Kayan villages in Balui had embraced Bungan (cf. Rouseau, 1998, p. 24). It was the Kayan of Long Linau who brought Adet Bungan to the Badeng of Long Geng. Informant Paga Kayang mentioned it was Jok Aging of Long Linau who introduced the reformed "religion" to Long Geng.

Bungan is one of the bali (spirits, god, goddesses) in the traditional religion but in Adet Bungan, the goddess Bungan has become the special focus of worship, hence the name of the new reformed faith. According to my informants, Pelegain (pronounced pələgain) is the highest bali ${ }^{6}$. Below him is Pesalong (pronounced Pəsalong) who created humans (oyan kelunan). Below them are many deities in charge of specific functions, most important of which is the female bali called Bungan who can communicate on behalf of the humans to Pelegain and Pesalong or other bali. For example, when one requests Bungan for a favor, such as blessing for a good harvest, the bali may on behalf of the humans requests Apau Lagan who is bali padai or paddy spirit to give the blessing. Another high bali is Bali Engkau, the Thunder Spirit. There are many other bali in charge of specific functions, such as Bali Oong who looks after a house, Bali Baliu who punishes people that tease animals (such as turning such people into rocks, baliu means to transform), Bali Tana' or earth spirit ${ }^{7}$, Bali Mudung (mountain spirit), etc. ${ }^{8}$ There is Bali Dayung, which according to informants, is rather troublesome as it demands various kinds of sacrifices such as chickens and pigs in exchange for seeking high bali like Pegain and Apau Lagan to give assistance to humans. Most bali like Pelegain, Pesalong, Bali Engkau and Bali Oong are male, while others like Bungan and Jangin Urai (bali in charge of rain) are female.

\footnotetext{
5 The Malay word adat for customs is pronounced adat in Kenyah and so I spell this word adet.

${ }^{6}$ I further found out more information about the Bungan beliefs from Siang Encau in August 2000. Born in Iwan when the Badeng were migrating from the Indonesian side of the border to Sarawak, Siang Encau was respected not only for his skill in playing Badeng music but also for his knowledge of Badeng history and culture. According to him Pelegain's father Wan Lati created the world (oyan tana'). Siang Encau mentioned that when the Badeng were at Tekulang before moving to Long Geng, the people still followed adat sui or "bird omen", i.e., the old religion.

When building a new house, pigs are slaughtered to present as sacrifice to Bali Tana'. Before the main poles are erected, pig's blood is poured into the holes.

${ }^{8}$ According to Sinag Encau, Təməkəling is bali buah, the bali in charge of fruits. To ask for medicine, pray to Təlangsio. For hunting, pray to Pəsəlong Asu. Other bali mentioned include Jangin Urai who is bali ujan or rain spirit, and Apui Anap who is bali loten or fire spirit.
} 
The reformation of old Kenyah and Kayan practices and the reformation in the form of Adet Bungan had external factors for Christian missionaries had become active and made headway in Central Borneo by the 1940s. In fact, Jok Apoi (spelled Jok Apuy in Rousseau, 1998) became a Christian. He remained poor and one day, he had a dream in which Bungan instructed him to reform the old religion and that he could eat things which were tabooed. Since then he introduced the new ways and his fortune turned better. Many villagers followed and renounced Christianity (cf. Rouseau, 1998, p. 23). The reformed ways which got rid of many taboos were welcome and the new faith spread in Central Borneo. Adet Bungan was obviously a revitalization movement in reaction to the new circumstances, which included the onslaught of Christianity that was ridding the indigenous practices, and the new consciousness arising from such religious encounters and which contributed to rethinking about the old ways. Jok Apoi provided the inspiration and leadership to reform the old ways by adopting Adet Bungan, which remained indigenous.

But Christianity had become a new force that continued to attract many people in Central Borneo. When I began to do research on the Badeng in 1989, some informants had mentioned to me about the Christian group called KINGMI, which the Badeng were familiar with before migrating to Sarawak. When Herbert L. Whittier did his research among the Lepo Tao Kenyah on the Kayan River on the Indonesian side of the Central Borneo in the early 1970s, he found that the people in Long Nawang had all become Christians, most of whom belonged to the "dominant fundamentalist sect" called KINGMI (Kemah Injil Gereja Masehi Indonesia), while a small number of people belonged to the church group called GPBI (Gereja Protestan Bagian Indonesia) (Whittier, 1978, p. 94).

In Long Geng Christianity eventually gained the upper hand, as Bungan followers converted to Christianity. In 1992, when I arrived at Long Geng, there were 150 apartments (amin) making up around 1,500 people, of which 34 amin followed Adet Bungan, 35 were Catholics and the rest SIB Christians. By my third visit in May 1995, there were only six amin which followed the Bungan way. In April 1994, the penghulu (regional headman) and his family converted to Catholicism. As a result, a few other families followed him, leaving behind only six families who remained as Bungan followers.

Despite the small number of Bungan followers left in Long Geng, I was able to learn and observe some Bungan practices. I soon learned that when there was a bunch of $j u l u t$ leaves hung at the door, this was a sign of malan or prohibition and one should not enter such an apartment. The Bungan followers in Long Geng had their places of worship at the RC (Roman Catholic) side of the village. They had their Uma' Bungan (Bungan House) and Uma' Bali (Spirits' house). I was able to take some photographs of the Bugan statue and statues of other bali by paying some money as ritual fine. However, I was not allowed to observe the nyat tana' rite even though it was at first arranged that I could do so by paying a fine. The rite was not open to people outside the Bungan faith, and it was too important a rite to risk offending Bungan to allow an anthropologist to observe it. I describe this rite from my interview as it was perhaps the only one performed while an anthropologist was in the village, before the death of a traditional Kenyah religion in the Belaga region. It will also provide some ideas about the Bungan practices and serve to contrast with the highly simplified Christian rite (see below).

A day before nyat tana' ("asking for land") rite, on 16 May 1995, the Bungan followers performed the nolat bali keratang or "propitiating the spirits of the deceased who may cause harms." The word nolat means to propitiate so that the spirits will not cause trouble or harm. Keratang refers to dangerous or harmful (ja'at) spirits of the deceased such as that of a woman who died during childbirth. The offering of chicken to these spirits was part of the ceremony to prepare the land for cultivation, so that the spirits would not disturb the 
preparation of the field as well as the planting of paddy. The offerings included slaughtered chicken, paddy, rice and money in the form of coins. The chicken was cooked for the feast, while the Bungan leader kept the paddy, rice and coins. On the following day, the Bungan leader led their followers to perform the nyat tana' rite. An offering of chicken was made to Bungan so that it would bless agricultural works and the growing of paddy. After this rite, the people could begin the first stage of the agricultural cycle, namely, lidik, or the clearing of undergrowth. Although the rite was called nyat tana', the land for the year was already chosen; the rite was to seek blessing and to ensure that there would be no harm.

The Christians, both the SIB and RC, talked of the relief from many prohibitions of the old custom. My main informant Okeng mentioned that before his father passed away in January 1978, his family had to kill so many pigs and chickens to perform ceremonies to cure his sick father. On the father's death, the family also had to spend on Bungan rites for the funeral. All these put the family in economic crisis. Thus on the following harvest, around April, he, his mother and his siblings all decided to convert to the RC. Okeng also mentioned about his close relative who died of childbirth in 1983. Bungan followers had a great fear of the bali or spirit of a woman who died of childbirth, and so no fellow Bungan followers helped to carry the deceased for burial. Thus Okeng, his brother and the woman's husband as well as two RC relatives carried the deceased for burial on the second day after death. A woman who died of childbirth had to be buried in very simple way. She was wrapped in a mat and carried out of the house from the back of the house. At the graveyard a relative had made a simple coffin and the corpse was put into the coffin and then buried. About a year later, the widower remarried, and converted to RC, choosing RC rather than SIB as it was the RC relatives who helped to carry his wife's corpse ${ }^{9}$. Here we see a person's own account of conversion. We shall now describe the process of the people who eventually all became Christians.

\section{Conversion to Christianity}

\section{Becoming SIB Christians: Village Fission and the Initial Exposure to Christianity}

The history of the SIB in Long Geng began around 1950s. When the people decided to move from Tekulang to Long Geng, they were divided into three groups. The majority went to Long Geng directly, a group stayed back at Tekulang and only later moved to Long Geng, and a group led by Iban Merang went to Long Malim. There were seven amin at Long Malim including a Lepo' Agak amin from the Baram, another river basin in Sarawak. According to Iban Merang, the people lived in Long Malim for eight years, but Tuan Phillips (pronounced Tuən Phillip in Kenyah) wanted all the Badeng originally from Tekulang to move to Long Geng. Iban Merang said that in order to migrate to Long Geng smoothly without having to observe various kinds of omens, he led his people to become SIB Christians. However, recent interview in June 2014 with a knowledgeable Badeng reveals that Iban Merang had led some people to Long Malim without the approval of the then headman and that he had intended to migrate (that is, return) to Kalimantan. This was a challenge to the headman who objected and he told him that he could leave without his Badeng relatives. Iban Merang was a Lepo' Tao (another group of Kenyah) from Kalimantan, and his Badeng wife was the headman's relative. Iban thus had no choice but to rejoin the Long Geng community.

Nevertheless, the point about becoming Christians to escape from the need of observing omens is significant. How did Iban Merang and his relatives learn about Christianity? We know that the Kenyah and

\footnotetext{
${ }^{9}$ I have compiled most of my ethnographic data up to 1995 in my unpublished report "The Badeng Kenyah of Long Geng: An Ethnographic Report”, 1995.
} 
Kayan of Central Borneo had heard about KINGMI while by the 1950s the Borneo Evangelical Mission (BEM) was already very active in interior Sarawak. Welcomed by the then Sarawak ruler Rajah Vyner Brooke in 1828 (Cunningham, 2002, p. 12), BEM aimed to preach to the indigenous people in inland Borneo. Those who had embraced the new faith spread the news when they visited relatives, including relatives who lived in different river basin. By the 1940s and 1950s, BEM had already had some success in converting the Kenyah in the Baram basin. One of my informants Ajan who had served as an "SIB worker" among the Badeng and Penan, said that his mother's Lepo' Aga (a group of Badeng) relatives in Long Jee' of the Baram basin had already converted to SIB Christianity. Some of the Lepo' Aga relatives came over to Long Malim, taking about eight days to walk over jungle terrain. They talked about Christianity, and upon their return to Baram, they mentioned to the SIB preacher Ray Cunningham about the Badeng interest in Christianity, which led him to go to Long Geng (see below). According to Ajan, his father and Iban Merang were the earliest SIB Christians of the Long Geng community.

Tuan Phillips mentioned by Iban Merang must be A. M. Phillips who was the Acting District Officer in Kapit from 8 April 1953 to 11 January 1954 and from 14 July 1954 to 17 January 1955. Thus Iban Merang's group must have arrived in Long Geng around the mid 1950s or not long thereafter. Another informant from the same longhouse with Iban Merang remembered that, in 1956, there were only 8 amin of SIB Christians. Later with the visit of the preacher whom the local people called Tagang (pronounced Tagəng), more people joined the SIB. Iban Merang mentioned that Tagang came to Long Geng around 1959. Having preached in the Baram, he spoke Kenyah fluently, so I was told, and his Kenyah name Tagang ${ }^{10}$ refers to the sharp iron piece attached to an areca nut tree (or fruit tree) to discourage people from climbing the trees to take the fruits without permission. Tegang also has the symbol of expelling evil. The older villagers in Long Geng remembered Tagang having preached briefly in their village. Tagang is actually Ray Cunningham who was from Australia ${ }^{11}$.

At first, all people of Long Geng lived on the right side of the river, but after two years, the other villagers were not happy with the presence of the Christians, and so it was agreed for the Christians to move to the other side of the river, and this led to the pattern of settlement in Long Geng. During the time of my research in Long Geng, all the SIB families were on the left side of the river except three amin who were on the RC side. There was an SIB church and a bigger new one was being built. There was a preacher (gembala) who was a Badeng from Data Kakus. The church was headed by a ketua siding, who was elected once in three years. He was assisted by 20 pelayan who were elected every year. These positions were prestigious as SIB had displaced all the traditional status system.

From the above, we know that the Badeng of Long Geng already heard about Christianity before their migration from Kalimantan (Indonesian side of Borneo) and the infrequent visits between them and their

\footnotetext{
10 This name was actually given by the Long Tebangan Kayan chief Jok Ngau, meaning "steadfast" (Cunningham 2002: 53).

11 The information from the field allows me to trace to Ray Cunningham's writing about his experience. I am grateful to Dr. Tan Jin Huat who helped me to acquire a copy of this book. Cunningham was a missionary of the Borneo Evangelical Mission (BEM), and in 1950 he was appointed to work with the Kayan at Long Tebangan in the Akah River of the Baram Basin in Sarawak. From there he was able to also preach to the Badeng at Lio Matu. Cunningham (2002: 65) mentions that in 1957 a Lepo' Aga man who returned from his visit to his relatives in Long Geng in the Belaga District reported that "a group of eight families" of the fifty-five families in Long Geng invited Christian mission to teach them about Christianity. This description corresponds very closely with my informant Iban Merang's account, including the eight families who were already Christians or in Cunningham's account wanted to learn the Christian way. However, Cunningham does not mention Iban Merang although he mentions the appointment of three Christian leaders, namely, Tama Kiin, Tama Gara and Tama Kusin (p. 74). Cunningham and his companions walked over the Usun Apau Mountain to Belaga, had an airstrip made at Long Geng, and flew back to Lio Matu after four months.
} 
relatives in the Baram river basin filled them with news about the SIB Christianity. The early claim to be Christians had to do with village politics, that of a small group trying to break away to form a new settlement with a new leadership. Although they failed and had to return to the village, they formed a core group willing to be Christians. The brief visit of Ray Cunningham helped to formally preached Christianity and was instrumental in consolidating the early group of self-declared Christians and converting others. While it was difficult to get sufficient information about the early conversion, it was obvious from my interview (see below about the conversion to Catholicism) that the early converts were active in persuading their relatives and fellow villagers to become Christians.

\section{The Roman Catholic (RC)}

It is not clear from the interviews when exactly $\mathrm{RC}^{12}$ was introduced to Long Geng. Lawai Laing, the main leader involved in leading the people to convert to RC, said that five years after settling in Long Geng, he led a few amin to join the $\mathrm{RC}^{13}$. Another main informant said that when he married in 1963, there was no RC yet in Long Geng. Nevertheless, it is clear that the long house called Uma' Katan Lawai, formerly under the leadership of Lawai Laing, was the earliest to join the RC. A Chinese Catholic priest, Anthony Wan, who had preached in the Baram and spoke Kenyah fluently, had played a role in introducing the Catholic faith to the people of Long Geng. However, according to Lawai Laing, Father John, a White man, was the earliest to visit Long Geng to preach the Catholic faith. According to my Badeng friend Okeng, Father John was from the Catholic Church in Belaga, and Lawai Laing was the first to convert to RC, around 1973. Recent interview with the SIB worker ${ }^{14}$ who had helped to preach SIB Christianity confirmed that the SIB villagers tried too hard to persuade Lawai to convert and he was so offended that he decided to lead some of his relatives to convert to RC. That was how the village was divided into SIB and RC.

\section{Understanding Conversion}

It is not easy to know the details of conversion over a length of time among an indigenous people who have no written record nor is there any official record or travelers' accounts. Nevertheless from my ethnographic interviews, we can reconstruct some details. We can better understand the process of conversion from a number of perspectives from the description so far, and we can construct the time frames from the scanty information available. From the above description it is clear that initially a few from this group of Badeng considered themselves Christians in the 1950s after migration from Tekulang to Long Geng. Most likely they were officially converted when the SIB missionary Tagang (Ray Cunningham) visited Long Geng in 1959. As 1950s was the active period of Bungan faith which was reformed out of adet puun (old customs), we can safely say that the few early conversions to Christianity took place in 1959 and the 1960s. These early converts were active in convincing their relatives to convert. Annoyed by the SIB persuasion, the influential old leader Lawai Laing led some families to convert to the Roman Catholics, hence the split of the community by religious affiliation. While he mentioned that this took place about five years after settling in Long Geng and given his age, the date given by the younger SIB activist is more reliable. The latter mentioned that when he married in 1963, there were no Roman Catholics in the village yet: this is more reliable since he remembered

\footnotetext{
12 This English abbreviation is used by the people even when they speak Badeng.

${ }^{13}$ Lawai Laing mentioned that at first there were only 7 amin who converted to RC, but at another part of the interview he mentioned about bringing 10 amin to join RC five years after settling in Long Geng.

${ }^{14}$ Interview with Ajan Jok at his home in Sungai Koyan Badeng Village on 10 June 2014.
} 
when he was married. Thus RC most likely began in Long Geng in the later part of the 1960s or early 1970s. I mention earlier that when I first arrived in the village in 1992, there were still 34 apartments of Adet Bungan followers, almost the same number as the Catholics (35 apartments), while the majority were SIB Christians (81 apartments). When the Long Geng Badeng were resettled in Sungai Koyan in 1998, only one Bungan person moved there, while the few other Bungans moved to Tekulang. Later in the 2000s, the only Bungan follower moved to Tekulang, and the Badeng in Sungai Koyan were all Christians. Thus we can establish the main timeline as follows-1950s-1960s: early conversion; 1970s-1980s: main period of conversion; 1990s: final period of conversion.

Now we can further understand the process of early conversion by locating this in the regional framework. Even the analysis of a remote interior community needs to be put in the larger regional perspective. We have seen that the people were already exposed to the Christian activities of the KINGMI in Kalimantan (Indonesian side of Borneo). In Sarawak, after James Brooke begun his rule as Rajah, he invited Christian missions as a way to consolidate his rule on the indigenous people. Different Christian missions were allocated different zones to conduct their missionary activities. The Baram basin was allocated to the Roman Catholic mission which established a mission base in Marudi in 1901 (Tan, 2012, p. 47). The Australian-based BEM which made its entry to Sarawak in 1928, was very successful in Limbang with many Lun Bawang conversions in the 1930s. In the 1940s, it made its headway to Upper Baram including the Badeng settlement at Lio Matu (Tan, 2012, p. 58). By the 1950s, it had reached various indigenous groups and an airplane was acquired to fly to the interior (Tan, 2012, p. 66).

In Sarawak the Badeng were distributed in Upper Baram and Belaga District. Despite the distance over difficult terrains, Badeng relatives did visit one another, and so the choice of a group of the Badeng in Long Geng to be Christians can be understood in this regional context, and we have seen the invitation of the BEM missionary to Long Geng, consolidating the SIB group there. Our case study and other accounts in Sarawak show that indigenous people who opted for Christianity were active in pondering for change and even welcome missionaries to help them become Christians. In fact, Cunningham reported that he found "people very interested, wanted us to teach them more" (Cunningham, 2002, p. 90).

The main period of conversion from the 1970s to the 1980s coincided with the period of active logging and frequent movement of people to work in the logging camps and in towns, while the 1990s saw them relocated to Sungai Koyan, another event of drastic change and adjustment. Logging had also opened up more contacts with outsiders and facilitated opportunities to sell them produce from the interior. With money earned from logging camps and opportunities to sell fish and game meat, the indigenous people also became more exposed to commoditization. Freedom from observing old taboos that Christianity offered became an attraction, while the lively Christian gatherings on Sundays were also an attraction. Church organization also became a convenient institution for discussing uncertainties brought about by logging and relocation to give way to dam building, all imposed by outside forces. Some younger people were also able to link up with church-linked NGOs to oppose logging which were destroying their habitat.

The villagers are linked by kinship, and relatives play an important role in conversion, too. This is not just through their direct persuasion of non-Christian relatives to convert, the latter were able to observe Christianity as practiced by relatives, and having observed that the Christians were able to continue with their indigenous ways of life without any disruption, and that communal life was not only not affected but in fact consolidated by Christian gathering, many eventually join the church, SIB or RC, on their own. While there is religiocentric 
bias against one another, there is no religious conflict between the SIB and RC Christians. Despite the diversity of religions, at death, all are buried at the same graveyard. The cognatic kinship which traces kin through both sides of the parents and the affinal relationship have resulted in the villagers being intensely related to one another. The kin relations bring the people together. Even at the height of the opposition to logging with rival views with regard to the government and the logging companies, the village meetings called by the regional headman were attended by people of both sides, and discussion was cordial, as I had observed. The elder people were addressed by the appropriate kin terms. Kinship matters. "Of course we Badeng are Christians," as the villagers would say. In this sense, while the act of conversion involves disruption and drawing boundary with the Bungan past, life after conversion is also characterized by cultural continuity as shown by the social life guided by kinship.

\section{Practicing Christianity}

Christianity transformed religious participation. When people followed the Bungan tradition, they had to depend on ritual specialists to communicate with the spirits, as Christians, people can pray to God directly. The Bungan rites involved older people and generally men, but as Christians, the Badeng of all ages and both sexes meet regularly and many including young people are able to play active roles in these meeting. The SIB Christians in Long Geng had church gatherings every Wednesday and Saturday evenings at 7:30 p.m. On Sunday, young people met to sing and pray from 6:30 a.m. before the Sunday service at $8 \mathrm{a} . \mathrm{m}$. In the afternoon at 2:00 p.m., there was a meeting for married men (kaum bapa) and one for married women (kaum ibu). Another gathering was held in the evening. A wooden gong was beaten before each gathering to call people to church. During the planting season, many people stayed in the fields and returned at the weekend for the church meetings. Thus on Monday morning the riverside was busy with people who were going to the fields by boat. It was a magnificent sight to see boat after boat leaving the village for the fields. When the clinic was opened (my first visit), it was busy, too, in the morning with people going to get medicine before leaving for the swiddens.

Once a month, most SIB Christians went to a nearby mountain to pray. There were two mountains which were chosen for the monthly meeting. One was further from the village, about two hours' climb, and the other was nearer, being less than an hour's walk from the village. On 6 June 1995, I attended the gathering at the nearby mountain. Early in the morning, those who wished to go to the mountain gathered to pray at the church at around 7:30 a.m. A leader was chosen, then the group set off in single file with women in the front and men at the back. On reaching the site after a steep climb, the people removed their shoes to enter the sacred area where there were wooden benches and a wooden podium for preaching. At the entrance, a man held up two stalks of fern leaves for each person to pluck a leaf on entering. This was to facilitate counting the number of people. There were altogether 68 persons.

There was singing of hymns and a long preaching about knowing Christ in Badeng by the leader of the day. After that there were prayers for the sick and also for the future of the people in view of the Bakun HEP. After the service, the people walked back to the village. In the evening, they attended church service during which the service at the mountain was reported. The mountain was called mudung pemanak or "families' mountain". The villagers described it as mudung bue' or "sacred mountain". It was believed that the site was originally chosen by the Holy Spirit who guided the believers to the spot. How the place was first chosen was a solemn affair. People who followed the leader guided by the Holy Spirit in search of the spot were not allowed to look backward. 
The Sunday service was a lively affair, with the use of drums and guitars to accompany singing, as is common of the SIB church meetings in Sarawak. The people generally dressed in their best. Both adult and children attended the service and it was a common sight to see a number of men and women coming to church carrying babies in baby carriers (bak anak). There was much singing and of course praying. The sermon tended to be long. As the hymn books and the bible are written in Malay ${ }^{15}$, the singing and reading of bible were generally in Malay, although there was also some singing in Badeng. The preaching and announcements were delivered in Badeng.

As to the RC Christians in Long Geng, they had a new Catholic church called Geraja St. John (St. John Church), which was officiated on 17 December 1994. Like the SIB, there were church meetings on Wednesday and Saturday evenings at 8 p.m. The one on Wednesday was for rosary while the meeting on Saturday involved more young people and was more informal. Both meetings were led by young people. Sunday service began at 8:30 p.m. A long wooden gong at the church was beaten twice each time to call people to a church meeting which seldom began on time. Singing of hymns continued until sufficient people had gathered. The atmosphere was informal - there might be children running about, at some point, a child might cry, or a dog might enter the church and someone might get up to chase it out.

When entering the church for the Sunday service, each villager dipped his or her right hand into the water in a bottle container at the entrance and then made a cross-sign (RC style) before entering the church. The seats were made of wooden benches. A few young people helped to lead the service although the main service was conducted by the lay preacher, locally referred to as ketegis (i.e. catechist). Unlike the SIB church, the RC church had only four pelayan (church elders). Announcements on village affairs (like the calling of a meeting) were usually made before the service proper. The medium of communication was Badeng although the reading of Bible and signing of some hymns were in Malay. Half-way through the service, donation was collected. Two sets of containers were used, each comprising a tin with a small belanyat (a kind of Kenyah rattan satchel) attached to it. The tin was for collection in kind (rice) and the belanyat was for cash collection. The service usually ended at around 10:00 a.m.

In 1998 the Badeng from Long Geng, like other Kenyah, Kayan and other communities in the upper Baliu River basin, were relocated to Sungai Koyan in Bintulu District to make way for the Bakun Dam Project. Some families from Long Geng refused to be relocated to the logged area in Sg. Koyan and instead moved to Long Lawen in their traditional Usun Apau region. At Sg. Koyan, the Long Geng Badeng settlement is similar to the Long Geng site with the SIB longhouses on one side and the RC long houses on the other side, except that they have only a small stream between them. The long houses and churches were built by the government, and the people used the compensation money they received from the government to pay for their apartments. Electricity and water are provided but the people have to pay monthly charges, something which the people took some time to get used to as there was no electricity supply in their former settlement and they obtained water from the river. There is a building built for the Bungan followers near the RC church, but there was only one Bungan follower here, and so the building was not used, and it was given to the RC church. The few other Bungan families joined those in Long Lawen. Siang Encau was the only Bungan follower in the Sg. Koyan Long Geng settlement, and he built a Bungan hut on the hill behind their apartment. Siang Encau lived among the RC Christians, but by my following trip in August 2008, he had moved to Long Lawen, and so the Badeng in Long

15 There is a Kenyah translation of the bible, mostly in Lepo Tau, but the younger generation of people who have been to school find it easier to read in Malay. There is also a Badeng hymn book entitled Nyanyi Aleluya, published by the SIB in 1990. 


\section{Geng were all Christians.}

The SIB Christians at the Sg. Koyan Long Geng settlement have their regular Sunday service as in the old settlement, and in August 2000 when I visited, the gembala (preacher) stationed there was a Kayan woman. Other than meetings at the church, the SIB Christians also go to a hill to worship on every first Saturday of the month. This place, called Gunung Doa, or the Prayer Hill, is the place where all SIB churches in Sungai Koyan have agreed to meet on the same day. However, on 5 August 2000 when I attended the worship, only the Long Geng group went to the hill. At around 8:30 a.m., after some prayer and singing at the SIB church in Long Geng, about 20 people went by a jeep and motorbikes to half way up the hill. There they sang and prayed including reciting the Lord's Prayer. They prayed for blessing for the day's worship at the mount. After that the people walked up a slope to a site where there were low log benches. A battery-run microphone was set up at the podium. A local leader led the worship and spoke in Badeng. Unlike in Long Geng, not so many SIB Badeng relocated in Sg Koyan join the worship at the mountain.

As to the RC church, it was named Gereja Joseph Pusat Badeng, Sg. Koyan, and was officiated by Rev. Fr. Anthony Wan on 22 December 1998. As in the old settlement, the Badeng RC church's closest link to the RC church beyond their own settlement is the Catholic Church in the district town Belaga, called Gereja Roman Katolik St. Francis Xavier. With the availability of electricity supply, the church at Sg. Koyan has fans and an electric guitar system for the church band. As in the old settlement, the RC Christians have regular services. I attended the Sunday service on 16 July 2000, which was from 9 a.m. to 10 a.m., but the young people in charge of the guitar and the drum had started to perform and sing along with those who arrived early. Most people went to the church at around 8:30 a.m. Like in the old settlement, there were children and often they were noisy, adding to the atmosphere of the church. As the people now have money received from compensation for the loss of their land and houses in Long Geng, they now give cash donation in church, and so only belanyat suluk (rattan carrying bags) were used to collect the donation during the Sunday service.

We see from the above description of the Badeng practice of Christianity that there are some modern changes from the 1980s when I first visited, when they lived in a remote part of Sarawak closer to Indonesia, to the 2000s when they had already been relocated to Sg. Koyan, still relatively remote but is accessible by a four-hour bumpy road journey from the coastal town of Bintulu. In Long Geng people led a largely subsistence life that depended on swidden cultivation, fishing, gathering and occasional hunting. By the 1980s, logging was beginning to affect the life of the people both ecologically and economically. Some people had found jobs at logging camps in different parts of interior Sarawak, and this provided opportunity to earn money, which eventually led to the commercialization of the Badeng community. With the money earned, some families were able to buy generators to provide electricity for their apartments. But the popular items in the 1980s and early 1990s were television sets and video equipment as these provided entertainments, mainly for watching Hong Kong produced dramas and sword fighting stories. The people perceived such changes as becoming "moden" which is derived from the Malay word for "modern". The effect could be seen in the church. With cash, the villagers were able to buy generators to light their churches and use microphones. It was in the 1990s with more people getting jobs in the logging camps and some young people going to coastal towns to work that more people have money to buy things. With money received from compensation because of relocation to make way for the Bakun Dam, the people in Sg. Koyan have become fully absorbed into the commercial economy even though many still practice swidden agriculture to plant hill rice. Donation in church is no more in kind, and electric guitars are used in church. Even a loud speaker is used when worshipping at the hill. 
While being modern is most visually seen in material term, the people also talk of the need of education for a modern life. On one occasion I listened to my key informant talking to his relatives in the longhouse that the Chinese parents cared about their children's education, that is why they are advanced and modern, and he commented that "we Badeng have not paid attention to our children's education". He stressed that the Badeng had to pay attention to education so as to be moden. This was just a casual conversation at the long-house porch. While the people did not say they converted to Christianity in order to be modern, Christianity no doubt facilitates modern changes. The sermons allow the local leaders to talk about the need of modern changes and there were frequent prayer not just for salvation but for good health, for better life, in short for better modern changes. The church organization that came with Christianity introduced new organization such as the formation of married men's gathering and married women's gathering as well as young people's gathering. The church organization also allows young people to play leadership roles, which in the past were monopolized by older people. In the case of the RC church where there is no Catholic father in charge, a few educated young people play leadership roles in leading church meetings. Having attended school, they are able to read the Bible and lead.

Whether SIB or RC Christians, the Badeng life today is very much guided by Christianity. The people generally do not go to work on Sunday and the Sunday service serves as a regulator of their weekly life. Those who go to the swiddens generally return towards the weekend for the Sunday service, which is always a joyful gathering enlivened by the use of guitars and drums at both the SIB and RC churches. In daily life, most people pray before dinner although some pray before every meal. It is a simple ritual and the short prayer, in Badeng of course, is always said by one of the persons who eat together. The wedding is conducted in the church with young people playing leading roles in handling the guitars, drums and singing, and the groom and bride wearing western-style suit and white bridal gown. The funeral is conducted in a simple Christian style with relatives attending and helping. When a person is sick, the people pray to God at church gathering. If the situation is serious, a small group of young people with someone carrying a guitar would go to the family concern to pray and sing hymns. Christmas is now the major annual celebration involving church meetings and soccer competition.

Christianity seems to have transformed the cultural life of the people, yet the change is not that drastic, and the people conduct their life as though there is no rupture, other than praying to a different god and conducting simpler rite, mostly praying together. Certain rituals need be conducted and these are now filled in by Christian ways. Instead of certain ritual specialists conducting traditional rites, now everyone, including women and young people, is involved, both in prayer and singing hymns. And indeed it is convenient and less expensive, no need to sacrifice a pig or chicken. We shall now describe more about conversion and indigenous culture.

\section{Conversion and Badeng Culture}

Conversion involves embracing a new religion and rejecting the old one. But it does not mean sudden and total rejection of a culture. To be sure, one's culture is altered by conversion, or as Marshall Sahlins comments "culture is historically altered in action" (Sahlins, 1985, p. vii) and "every practical change is also a cultural reproduction" (Sahlins, 1985, p. 144). In this respect, his conception of "structural transformation" is useful. Conversion involves rejecting the gods and goddess of the Bungan religion and not conducting Bungan rites. In the cultural order of the Badeng, this is replaced by the Christian God which does not require observing traditional taboos. Even in the Bungan faith the cultural taboos were reduced; Christianity abolished all of them. 
The Christian cosmology easily takes the place of those aspects of Bungan cosmology that are rejected, for example, the Christian creation replaces the Bungan myths of creation. Not all aspects of indigenous cultural categories are discarded. The idea of "bali" which refers to all kinds of spirits remains important. Staying with the Badeng, one often hears this word "bali". For example, when there is a strange event or a sudden strong wind, the Badeng may say "un bali" (there is spirit/ghost).

While conversion is a disruptive act, the cultural consequence of conversion is not as disruptive as it appears. The Bungan rites are not performed, but the need for divine blessing on each occasion is still observed with a simple Christian prayer in the Church. For instance, in place of the Bungan nyat tana' rite, the SIB Christians have the local preacher say a prayer during a Sunday service preceding the beginning of the agricultural cycle. In a sense, the rite is still observed, only that it involves a simple Christian prayer at a congregation. The RC Badeng, however, still keep some resemblance of the old rite by having the villagers bringing knives, axes and other tools related to the clearing of land to the church and placing them on the floor in front of the podium for the Christian blessing, as I had observed on 23 April 1995. At the end of the church service, the owners took back their tools. Thereafter, the people could begin to clear their chosen piece of land for planting rice in the new agricultural cycle.

There were other rites which could be performed in a simple Christian fashion. For example, on 23 April 1995, immediately after the RC church service, most people went to an apartment in Uma' Daya (name of a long house) to participate in the blessing of the new paddy engine room, where paddy would be unhusked by using the engine. The people gathered in the living room, while some women were busy preparing food and drinks in the kitchen. At around 11 a.m., the ceremony began with the singing of hymns and praying. Eventually, the catechist and an assistant (pelayan) went to the engine room near the longhouse to bless (melewa) the ingin padi ("paddy engine") and a new boat engine there. At the engine room, the catechist prayed to God for blessing, after which he sprinkled each engine and the room with "holy" water. Having performed the rite, he and the pelayan returned to the apartment where people had continued to sing hymns. After some more praying, including a prayer of thanks, a few girls brought out drinks, biscuits and fried bihun (rice-flour noodle) ${ }^{16}$, and placed them in the center of the room. They served the people who sat along the edge of the room. There were around 60 persons. After eating (which was lunch), some people returned home. The women collected the plates and cleaned up the place. Others stayed to have a session of borak (rice beer) until late afternoon.

Another important rite which the RC Christians still practice but in a Christian way is oyan obek. This is a pre-harvesting rite elaborately performed before the Bungan people converted to RC. Before harvesting, when the paddy was not yet fully ripe, each family would take some obek, the not yet fully ripe paddy, from the field. The paddy had to be removed from the stalk by hand, a process called megut obek. After that, the paddy was pounded to unhusk them, then they were rid of the chaff by napan, winnowing by throwing the rice in a tapan, a pear-shaped rattan tray. The obek was then fried so as to be ready for eating. On a chosen day, the Bungan leader would perform the léwa obek rite (rite of offering obek). The blood of a pig was smeared onto the kelebu, the fine strips cut out of the tip of a stick and still attached to it (usually to ease burning). Each amin received a piece of the blood-smeared kelebu, which thus symbolized that a sacrifice (léwa) had been made. The head of each apartment would take the léwa obek (obek sacrifice) as represented by the piece of kelebu and perform a

\footnotetext{
${ }^{16}$ As in Malay, bihun is derived from the Hokkien pronunciation of mifen in Mandarin, which refers to the noodle made of rice-flour.
} 
symbolic act over the fried obek. He then ate some obek, followed by the rest of the people in the apartment. Usually it was the children who rushed to get (punan) the obek, the adults did not eat much.

The oyan obek rite was an occasion when the dayung (human medium with the dayung) sought the bali's permission to harvest. Only after this rite could harvesting begin. Now that the people have become Catholics, the rite is modified and simplified. On a chosen day, a member from each amin brings the respective apartment's obek to the church, and pours them into a common container. After a simple Christian blessing, the people will punan (grab) some obek to eat. After that, harvesting can begin.

Both the SIB and RC villagers in a sense still observe the old rule of invoking spiritual blessing on specific occasion, but the RC villagers still retain some resemblance of the old rites, at least by having a simple commensal meal after the blessing, and at each commensal "feasting", there are prayers by different individuals. As I analyze and relate to relevant works, I find the Badeng case is similar to the experience of conversion among the Maisin in New Guinea studied by John Barker (2012). He attributes the gentle experience of the transition to Christianity to the attitudes of the local church leaders and the loose supervision of the district missionaries. In the case of the Badeng that I have studied, there was no missionary center nearby. The people managed their own transition to Christianity although the SIB Christians facilitated by the more charismatic SIB networks beyond the village are more exposed to the exclusive SIB ideology of rejecting non-Christian traditions. In practice the local SIB attitude is expressed in the strict rule against smoking and drinking alcohol drink and regarding their RC relatives as not good Christians. The SIB villagers are also stricter in rejecting Bungan symbols. Thus when making crafts they generally avoid making designs of traditional spirit (bali), while the $\mathrm{RC}$ villagers continue to use such bali designs. On the other hand, the RC villagers regard the SIB Christians as unnecessarily strict and tease about SIB youths coming to their RC long houses to drink rice beer and some smoke when they go to town. While SIB leaders may comment about their RC relatives as not having good Christian ethics, there is no condemnation and they even tolerated one of their leaders who continued to smoke tobacco until he passed away.

\section{Conclusion}

This article describes the religious changes among the Long Geng Badeng, how they had changed from their reformed indigenous Bungan religion to Christianity. The Badeng conversion occurred at a time of increasing encounter with the outside world in the 20th century. The encounter with Christianity in Central Borneo provided an alternative to the traditional religious practices and an inspiration to some local thinkers - the indigenous people have thinkers too-who articulated the need for reform. Christianity was not "forced" on the people as a result of intense missionary activities; it was initially chosen by some local people, and the visits of the few missionaries of different traditions helped to formalize and reinforce conversion.

From my research and interviews, it is clear that the Badeng were active agents in choosing to adopt Christianity, which helped them to be freed of a number traditional taboos that their traditional religion demanded them to observe. This allowed them to adjust more conveniently to living in a world that was becoming more engaged with outside forces. The reformer of the indigenous "Old Custom", Jok Apoi, not only was exposed to Christianity, he in fact converted to Christianity and then left the new religion to reform the Kayan indigenous religious practices into a reform movement called Bungan. And in Long Geng, Bungan gave way to Christianity until the indigenous religion disappeared. With more and more people turning to Christianity, the Bungan followers were left with fewer and fewer support among themselves, and the contrast 
of the convenience of life without prohibitions and of religious practices without any economic cost, except for the volunteered church donation, was too obvious. The Badeng have chosen to abandon their reformed traditional Bungan faith. Both the conversion of leaders and relatives had led to more and more people to adopt Christianity.

We can say that the Long Geng Badeng have chosen Christianity as a way of adjusting to changing times. This is not to say that Christianity is necessary for such an adjustment; it arrived at a time when some Badeng leaders were feeling the need of reforming their traditions, and Christianity provided an alternative for change. Since then, the Badeng have been moving a lot to towns and places of work and also for schooling. The many old prohibitions would have to be reformed one way or another, with or without Christianity. The Badeng had found it convenient to convert to Christianity in the 1950s, and it was relevant to note that the early leaders who were instrumental in convincing people to convert all mentioned that converting to Christianity helped to avoid the need of observing the many old rules of prohibitions. Conversion was an active choice at a time when they found that they needed to adjust to changes of the time, including meeting more outsiders, going out to work, finding ways to get modern medicine as well as to revitalize their local community.

Not all aspects of a people's culture are good and functional all the time, hence the need for cultural change and reform. Some aspects of culture like funeral rites and agricultural rites are too imposing for individuals within a culture not to follow; but religious conversion can be a way of escaping from this kind of "cultural trap", as I have seen of Chinese relatives and friends converting to Christianity with this intention. As to reform within a culture, the Chinese May Fourth Movement of the early 1920s is an extreme example with many reformers blaming traditional cultural practices, including Confucianism, as hindering modernization, and called for total rejection (cf. Chow, 1960). The point is that in all societies, including those of indigenous peoples, there are individuals who call for cultural reformation.

Robert Hefner has provided a balanced critique of Robin Horton's intellectual model of conversion (Horton, 1975a; 1975b) for its neglect of "political and structural influences on conversion" (Hefner, 1993a, p. 22). We need to take note of both intellectual and political economy factors of cultural change. Our analysis of the Badeng conversion takes note of both the internal rationalization and regional influences. It shows that the Badeng conversion involved both the people's own reflection of their own old tradition as well as assessment of external influences. In view of the easy explanation of conversion for access to modern facilities and for drawing boundary with the majority people, there is a need to draw attention to people's rationalization over a long period of time, as illustrated in our Badeng case.

Religious change provides the opportunity to renegotiate tradition and modernity, to redefine tradition and even to drop some old customs. Conversion brings about a new identity, how this is re-composed depends on the kind of Christian ideology embraced and hence the scope of incorporating old traditions into the Christian framework. We have seen the contrasting perspectives and identities of the SIB Badeng and the RC Badeng. The former condemn all old traditions associated with the Bungan while the latter successfully re-compose some old traditions in Christian way. Despite theological differences and bias between them, they see themselves and relate to the external world as Christians.

In converting to Christianity, the Badeng obviously adopt a new cultural category; adopt in the sense of "taking on something new" (Robbins, 2004, p. 11). The conversion is both disruptive and not so disruptive; disruptive in the act of conversion that requires rejecting the traditional Bungan religion and its forms of rites; not so disruptive in the sense that the Badeng are able to go on with their socio-economic life as usual, only that 
the Christian rites have replaced the Bungan rites and in some cases the old rites are reproduced with Christian form as in the rite of beginning a new agricultural year.

The Badeng have adopted Christianity and integrated it into their way of life, which is also thereby transformed. This demonstrates Marshall Sahlin's view that "culture functions as a synthesis of stability and change" (Sahlins, 1985, p. 144). So is his concept of "structure of the conjuncture" meaning "the practical realization of the cultural categories in a specific historical context" (Sahlins, 1985, p. xiv). In a sense, Christianity has replaced Bungan in its relationship with the other Badeng cultural categories. The new cultural reproduction then shows both cultural continuity and change (aspects transformed by the practice of Christianity). Overall the exposure to Christianity, the convenience of abandoning traditional taboos which hinder frequent travel and engaging in all kinds of economic activities, and the influence of kin all help to explain the conversion of the Badeng to Christianity over a period of time and the eventual despise of the traditional Bungan religion.

\section{References}

Amster, M. H. (2009). Portable potency: Christianity, mobility and spiritual landscapes among the Kelabit. Anthropological Forum, 19(3), 307-322.

Aragon, L. V. (1996). Recognizing the cosmology: The reinterpretation of deities and religious practice by Protestants in Central Sulawesi, Indonesia. Journal of Southeast Asian Studies, 27(2), 350-373.

Armstrong, R. (1991). People of the same heart: The social world of the Kenyah Badeng (Ph.D. thesis, University of Sydney).

Armstrong, R. (1994). From difficult natives to good citizens: Marginality and autonomy in a Central Borneo society. ASSESS Journal (Australia), 1, 36-47.

Barker, J. (1993). "We are Ekelesia": Conversion in Uiaku, Papua New Guinea. In R. F. Hefner (Ed.), Conversion to Christianity: Historical and anthropological perspectives on a great transformation (pp. 199-230). Berkeley and Los Angeles, Cal.: University of California Press.

Barker, J. (2012). The Enigma of Christian conversion: Exchange and the emergence of new great men among the Maisin of Papua New Guinea. In L. Dousset and S. Tcherkézoff (Eds.), The scope of anthropology: Maurice Godelier's work in context (pp. 46-66). New York: Berghahn Books.

Cannell, F. (Ed.). (2006). The anthropology of Christianity. Durham and London: Duke University Press.

Chong, C. C. (1996). Wanita di ulu: Satu kajian kes di Long Bulan (Kenyah Uma Bakah), Daerah Belaga, Sarawak [Women in the interior region: A case study in Long Bulan (Uma Bakah Kenyah), Belaga District, Sarawak] (BA thesis, Department of Anthropology and Sociology, University of Malaya).

Chow, T.-T. (1960). The May Fourth Movement: Intellectual revolution in modern China. Cambridge: Harvard University Press.

Chua, L. (2012). Conversion, continuity, and moral dilemmas among Christian Bidayuhs in Malaysian Borneo. American Ethnologist, 39(3), 511-526.

Coleman, S. (2000). The globalisation of charismatic Christianity: Speaking the gospel of prosperity. Cambridge: Cambridge University Press.

Comaroff, J. (1985). Body of power, spirit of resistance: The culture and history of a South African people. Chicago and London: The University of Chicago Press.

Comaroff, J., \& Jean. (1992). Ethnography and the historical imagination. Boulder, Co.: Westview Press.

Cunningham, R. (2002). Longhouses open doors: God's glory in Borneo. Ormond, Vic. (Austrsalia): Hudson Press.

Hayami, Y. (1996). Karen tradition according to Christ or Buddha: The implications of multiple reinterpretations for a minority ethnic group in Thailand. Journal of Southeast Asian Studies, 27(2), 334-349.

Hefner, R. W. (1993a). Introduction: World building and the rationality of conversion. In R. F. Hefner (Ed.), Conversion to Christianity: Historical and anthropological perspectives on a great transformation (pp. 3-44). Berkeley and Los Angeles, Cal.: University of California Press.

Hefner, R. W. (1993b). Of faith and commitment: Christian conversion in Muslim Java. In R. F. Hefner (Ed.), Conversion to Christianity: Historical and anthropological perspectives on a great transformation (pp. 99-125). Berkeley and Los Angeles, Cal.: University of California Press. 
Horton, R. (1975a). On the rationality of conversion: Part one. Africa, 45, 219-235.

Horton, R. (1975b). On the rationality of conversion: Part two. Africa, 45, 373-399.

Jehom, W. J. (2008). Development and displacement: Kenyah-Badeng in Bakun Resettlement, Malaysia (Doctoral thesis, Rheinischen Friedrich-Wilhelms-Universitatät zu Bonn).

Kammerer, C. A. (1996). Discarding the basket: The reinterpretation of tradition by Akha Christians of Northern Thailand. Journal of Southeast Asian Studies, 27(2), 320-333.

Keyes, C. F. (1996). Being Protestant Christians in Southeast Asian worlds. Journal of Southeast Asian Studies, 27(2), $280-292$.

Kirsch, T. (2008). Religious logistics: African Christians, spirituality and transportation. In F. Pine and João de Pina-Cabral (Eds.), On the margins of religion (pp. 61-80). New York: Berghahn Books.

Lees, S. (1979). Drunk before dawn. Kent: Overseas Missionary Fellowship.

McDougall, D. (2009). Rethinking Christianity and anthropology: A review article. Anthropological Forum, 19(2), 185-194.

Robbins, J. (2007). Becoming sinners: Christianity + moral torment in a Papua New Guinea society. Berkeley: University of California Press.

Robbins, J. (2007). Continuity thinking and the problem of Christian culture: Belief, time, and the anthropology of Christianity. Current Anthropology, 48(1), 5-38.

Robbins, J. (2010). Anthropology, Pentecostalism, and the new Paul: Conversion, event, and social transformation. South Atlantic Quarterly, 109(4), 633-652.

Rousseau, J. (1998). Kayan religion: Ritual life and religious reform in Central Borneo. Leiden: KITLV Press.

Sahlins, M. (1985). Island of history. Chicago: The University of Chicago Press.

Tan, C. B. (1997). The Badeng of Sarawak. Journal of Malaysia Studies, 15(1\&2), 148-174.

Tan, C. B. (2009). Skilled craftsmanship from Interior Borneo: Badeng traditional crafts and their future. In A. R. Walker (Ed.), Pika-Pika: The flashing firefly: Essays for Pauline walker by her friends in the arts and social sciences (pp. 219-237). New Delhi: Hindustan Publishing Corporation.

Tan, J. H. (2011). Planting an indigenous church: The case of the Borneo evangelical mission. Oxford: Regnum Books International.

Tomlinson, M. (2009). In God's image: The metaculture of Fijian Christianity. Berkeley: University of California Press.

Vom, R. (1993). The migration of Kenyah Badeng: A study based on oral history. Edited with an introduction by Tan Chee-Beng. Kuala Lumpur: Institute of Advanced Studies, University of Malaya.

Whittier, H. L. (1978). The Kenyah. In V. T. King (Ed.), Essays on Borneo societies (pp. 93-122). Oxford: Oxford University Press. 